\title{
Peningkatan Hasil Belajar Servis atas Permainan Bolavoli dengan Menggunakan Metode Drill dan Bermain
}

\author{
Umi Hazinah
}

\author{
SDN Turi 1 Kecamatan Sukorejo Kota Blitar \\ Email: umihazinah@yahoo.com
}

\section{Tersedia Online di \\ http://www.jurnal.unublitar.ac.id/ index.php/briliant}

\begin{tabular}{l}
\hline Sejarah Artikel \\
\hline Diterima pada 10 Juli 2017 \\
Disetuji pada 24 Juli 2017 \\
Dipublikasikan pada: 2 Agustus \\
2017 Hal 378-391 \\
\hline
\end{tabular}

Kata Kunci:

hasil belajar, bolavoli, drill dan bermain

\begin{abstract}
Abstrak: Penelitian ini merupakan penelitian tindakan kelas yang dirancang dengan dua siklus. Setiap siklus terdiri dari dua pertemuan. Penelitian ini dilakukan untuk memecahkan masalah tentang rendahnya nilai hasil belajar siswa dalam mata pelajaran Pendidikan Jasmani khususnya tentang bolavoli. Data dalam penelitian ini dikumpulkan melalui observasi guru dan siswa serta tes. Hasil akhir dari penelitian ini menunjukkan peningkatan hasil belajar siswa dengan kenaikan hasil belajar pada tiap siklusnya. Rata-rata hasil belajar pada siklus I sebesar $72,29 \%$ dan meningkat pada siklus II sebesar $81,66 \%$.
\end{abstract}

Siswa dalam pembelajaran Pendidikan Jasmani sebagai individu yang sedang berkembang. Kemampuan belajar seseorang akan dipengaruhi oleh tingkat perkembangan dan keluasan pengalaman yang dimilikinya. Anak bukanlah orang dewasa dalam bentuk kecil, melainkan organisme yang sementara berada pada tahap-tahap perkembangan. Kemampuan belajar akan sangat ditentukan oleh tingkat perkembangan dan pengalaman mereka. Dengan demikian, peran guru bukanlah sebagai instruktur atau "penguasa" yang memaksakan kehendak, melainkan guru adalah pembimbing siswa agar mereka dapat belajar sesuai dengan tahap perkembangannya.

Siswa memiliki kecenderungan untuk belajar hal-hal yang baru dan penuh tantangan. Kegemaran anak adalah mencoba hal-hal yang dianggap aneh dan baru. Oleh karena itulah, belajar bagi mereka adalah mencoba memecahkan setiap persoalan yang menantang. Dengan demikian, guru berperan dalam memilih bahan-bahan belajar yang dianggap penting dipelajari oleh siswa.

Penggunaan metode yang tepat bagi siswa akan memudahkan pelaksanaan proses belajar mengajar guna mencapai tujuan yang telah ditetapkan. Adapun salah satu metode yang dapat digunakan untuk meningkatkan kemampuan servis bolavoli yaitu metode drill dan bermain. Dari kedua metode tersebut masing-masing memiliki karakteristik yang berbeda dan belum diketahui metode mana yang lebih baik dan efektif untuk meningkatkan hasil belajar servis atas dalam permainan bolavoli pada siswa kelas VB SDN Turi 1 yang sedang dalam taraf belajar teknik dasar bola voli. Untuk mengetahui hal tersebut perlu dibuktikan melalui penelitian. 
Rendahnya nilai hasil belajar siswa menggambarkan rendahnya tingkat kemampuan siswa pada mata pelajaran tersebut di atas. Pada mata pelajaran Pendidikan Jasmani dari 25 siswa kelas VB SDN Turi 1 hasil tes formatif tentang servis atas permainan bolavoli dibawah nilai rata-rata yaitu 19 anak yang belum tuntas. Jelas sekali terlihat bahwa adanya perbedaan tentang kenyatan di lapangan dengan tujuan yang diharapkan pada kurikulum, juga dengan harapan yang di inginkan guru dan peneliti pada umumnya yaitu siswa dapat mengikuti setiap pembelajaran dengan antuasias atau semangat sehingga dapat mencapai nilai akhir dengan rata-rata $<75$.

Berdasarkan data tersebut peneliti tertarik untuk melakukan Penelitian Tindakan Kelas, dalam upaya memperbaiki nilai mata pelajaran Penjas di kelas VB dengan judul penelitian : "Meningkatkan Hasil Belajar Siswa pada Mata Pelajaran Pendidikan Jasmani dan Kesehatan tentang Servis Atas Permainan Bolavoli dengan Menggunakan menggunakan metode drill dan Bermain di Kelas VB SD Negeri Turi 1 Kecamatan Sukorejo Kota Blitar".

Berdasarkan uraian di atas, masalah yang dianalisis dalam penelitian ini dirumuskan sebagai berikut : 1 . Bagaimana penggunaan metode drill dan bermain dapat meningkatkan hasil belajar siswa tentang konsep servis atas permainan bolavoli di kelas VB SDN Turi 1 Kecamatan Sukorejo kota Blitar ? 2. Apakah penggunaan metode drill dan bermain dapat meningkatkan aktifitas belajar siswa tentang konsep servis atas permainan bolavoli di kelas VB SDN Turi 1 Kecamatan Sukorejo kota Blitar?

Penelitian ini bertujuan untuk meningkatkan hasil belajar siswa pada mata pelajaran Penjas di kelas VB pada SD Negeri Turi 1, untuk lebih jelasnya tujuan penelitian ini dijabarkan sebagai berikut : 1 . Untuk mendiskripsikan penerapan hasil belajar siswa dengan menggunaan metode drill dan bermain tentang konsep servis atas permainan bolavoli ? 2. Untuk mendiskripsikan peningkatan aktifitas belajar siswa tentang konsep servis atas permainan bolavoli

Belajar adalah proses perubahan individu yang relatif tetap sebagai hasil dari pengalaman, sedangkan pembelajaran merupakan upaya penataan lingkungan yang memberi nuansa agar program tumbuh dan berkembang secara optimal. Oleh karena itu proses belajar bersifat internal dan unik dalam diri individu siswa, sedangkan pembelajaran bersifat eksternal yang sengaja direncanakan yang bersifat rekayasa perilaku. Sedangkan pembelajaran berorientasi pada aktifitas siswa menghendaki keseimbangan antara aktifitas fisik, mental termasuk emosional dan aktifitas intelektual.

Menurut Herry Koesyanto (2003:10), belajar adalah berusaha atau berlatih agar mendapatkan kepandaian. Arti belajar dasar bermain bolavoli tak lain adalah berlatih teknik dasar bolavoli agar terampil dalam bermain bolavoli. Adapun teknik dasar bolavoli yang dapat dipelajari diantaranya adalah teknik dasar servis, pas (passing), umpan (set-uper), smash, dan bendungan (block).

Servis merupakan salah satu teknik dalam permainan bolavoli. Pada mulanya servis hanya merupakan pukulan awal untuk dimulainya suatu permainan, tetapi jika ditinjau dari sudut taktik sudah merupakan suatu serangan awal untuk diperoleh nilai agar suatu regu berhasil diraih kemenangan (M. Yunus, 1992:68-69). Pendapat serupa juga dinyatakan Beutelstahl (2005:9), bahwa mulanya servis hanya dipandang sebagai pukulan permulaan saja, cara melempar bola untuk memulai permainan. Tetapi servis kemudian berkembangan menjadi 
suatu senjata yang ampuh untuk menyerang. Servis harus dilakukan dengan baik dan sempurna oleh semua pemain, karena kesalahan pemain mengakibatkan pertambahan angka dari lawan dan uniknya lagi setiap pemain harus melakukan servis ini. Demikian pentingnya kedudukan servis dalam permainan bola voli, akan teknik dasar servis harus dikuasai dengan baik. Oleh karena itu servis harus keras dan terarah dengan tujuan agar tidak mudah diterima oleh lawan yang berarti pihak pemegang servis mendapatkan angka.

Servis ada bermacan-macam, di mana masing-masing memiliki nama, sifat dan teknik sendiri-sendiri. Menurut Suharno HP. (1989:12), ada dua macam pukulan servis yang di kenal dan sering dimainkan yaitu servis tangan bawah dan servis tangan atas. Servis atas adalah servis yang sering digunakan oleh pemain pemula, karena servis ini merupakan servis yang sangat sederhana dan mudah. Gerakan servis atas lebih alamiah dan tenaga yang dibutuhkan tidak terlalu besar (M. Yunus, 1992:69). Jadi servis ini sesuai diajarkan terutama untuk pemain yang masih dalam taraf belajar/berlatih seperti anak sekolah.

Pembelajaran servis atas dengan metode konvensional dilakukan dengan drilling atau latihan secara terus menerus. Sugiyanto (1993:371) menyatakan, dalam metode drill siswa melakukan gerakan-gerakan sesuai dengan apa yang diinstruksikan guru dan melakukannya secara berulang-ulang. Pengulangan gerakan ini dimaksudkan agar terjadi otomatisasi gerakan. Oleh karena itu, dalam metode drill perlu disusun tata urutan pembelajaran yang baik agar siswa terlibat aktif, sehingga akan diperoleh hasil belajar yang optimal. Lebih lanjut (Sugiyanto, 1993:372).

Menurut Armai (2002: 175) langkah-langkah metode drill adalah : 1) Siswa terlebih dahulu dibekali degan pengetahuan teori. 2) Guru memberikan contoh latihan. 3) Guru memberikan latihan teknik dan dilakukan siswa kemudian di bimbing oleh guru. 4) Guru mengoreksi dan membetulkan kesalahan kesalahan latihan yang dilakukan siswa.

Metode bermain pada prinsipnya untuk memenuhi hasrat gerak anak agar menimbulkan rasa senang bagi diri mereka. Dalam hal ini Yusuf Adisasmita dan Aif Syaifuddin (1996:144) berpendapat, latihan melalui kompetisi-kompetisi merupakan salah satu kegiatan yang lebih efektif dan para atlet senang melakukannya. Dengan bermain anak akan mengekspresikan kegembiraannya dan berusaha menampilkan kemampuannya. Namun disisi lain seorang guru harus menanamkan sikap sportivitas, karena dalam bermain ada yang menang ada yang kalah. Seperti dikemukakan Rusli Lutan (1988:37) bahwa, karena permainan, akan menyebabkan adanya yang kalah dan yang menang, maka guru harus pula mengembangkan sikap seorang yang menang dan sikap seorang yang kalah secara fair kepada siswa, karena sikap seperti itu tidak terbentuk dengan sendirinya melalui permainan, maka usaha pengembangan sikap ini harus dilakukan secara terencana dan disengaja oleh guru.

Berdasarkan pendapat tersebut menunjukkan bahwa, metode bermain di dalamnya terkandung pembelajaran yang cukup kompleks yaitu penguasaan teknik cabang olahraga yang dipelajari, penerapan taktik yang baik dan memecahkan masalah yang terjadi di dalam permainan serta pembentukan sikap mental yaitu saling menghargai.

Jika belajar diartikan suatu proses tingkah laku, maka perubahan tingkah laku yang diharapkan disebut hasil belajar. Hal ini sesuai dengan yang

380 BRILIANT: Jurnal Riset dan Konseptual

Volume 2 Nomor 3, Agustus 2017 
diungkapkan oleh Alisuf Sabri (1995 : 55) hasil belajar adalah perubahan tingkah laku sebagai akibat pengalaman atau latihan, perubahan tersebut dapat berupa perilaku yang baru atau memperbaiki prilaku yang ada.

Secara umum, hasil belajar yang akan dicapai siswa dipengaruhi oleh 2 faktor utama yaitu faktor internal (faktor siswa itu sendiri) dan faktor eksternal (lingkungan). Sementara Caroll (dalam Nana Sudjana, 1989 : 30) membagi faktorfaktor yang mempengaruhi hasil belajar menjadi lima yaitu (1) Bakat belajar (2) Waktu yang tersedia untuk belajar (3) Waktu yang diperlukan siswa untuk menalarkan / menyerap pelajaran (4) Kemampuan siswa (5) Kualitas pengajaran

Poin 1, 2, 3, 4 berkenaan dengan faktor internal, sedangkan poin 5 merupakan faktor eksternal. Kualitas pengajaran merupakan salah satu lingkungan belajar yang cukup dominan mempengaruhi hasil belajar di sekolah, yang dimaksud dengan kualitas pengajaran adalah tinggi rendahnya atau efektif tidaknya proses belajar mengajar dalam mencapai tujuan pengajaran.

\section{METODE}

Penelitian ini dilaksanakan di SDN Turi 1 Kota Blitar. Lokasi penelitian ini beralamat di Jalan Beringin No 322 Kecamatan Sukorejo Kota Blitar.Waktu pelaksanaan: Siklus 1 Pertemuan 1 dilaksanakan pada tanggal 23 Agustus 2016, Siklus 1 Pertemuan 2 dilaksanakan pada tanggal 30 Agustus 2016, Siklus 2 Pertemuan 1 dilaksanakan pada tanggal 6 September 2016, Siklus 2 Pertemuan 2 dilaksanakan pada tanggal 13 September 2016.

Subjek penelitian ini guru olahraga yang melakukan penelitian terhadap siswa kelas VB SDN Turi 1 Kota Blitar pada semester ganjil tahun ajaran 2016/2017 dengan jumlah siswa sebanyak 25 siswa, terdiri dari 10 siswa laki-laki 15 siswa perempuan

\section{Prosedur Penelitian}

Metode yang digunakan dalam penelitian ini adalah metode kuantitatif dengan jenis penelitian tindakan kelas. Penelitian dilaksanakan sebanyak 2 siklus masing masing siklus terdiri dari 2 kali pertemuan. Setiap siklus melalui tahapantahapan yaitu tahap perencanaan, pelaksanaan, observasi dan refleksi. Berikut rancangan yang digunakan dalam pelaksanaan penelitian. Peneliti menggunakan model PTK yang dikembangkan oleh Kemmis dan Taggart (1990). Adapun langkah dari penelitian ini meliputi perencanaan, pelaksanaan, observasi dan refleksi.

Pada tahap perencanaan peneliti melakukan: (1) memilih materi yang akan dipelajari siswa. (2) Merancang Rencana Pelaksanaan Pembelajaran (RPP) dengan metode Drill, (3) menyiapkan alat atau instrumen pengumpul data yang akan digunakan untuk pengumpulan data yaitu berupa lembar observasi kemampuan guru selama proses pembelajaran dengan menggunakan metode Drill,lembar kerja Siswa (LKS), butir soal dan jawaban tes individu, lembar observasi siswa selama proses pembelajaran dengan menggunakan metode Drill, lembar catatan lapangan siswa serta kamera untuk keperluan dokumentasi berupa foto saat kegiatan pembelajaran.

Pada tahap ini peneliti mempraktikkan pembelajaran sesuai dengan Rencana Pelaksanaan Pembelajaran (RPP) yang telah disusun. Pelaksanaan pembelajaran dilakukan sesuai dengan skenario pembelajaran yang telah dibuat 
agar kegiatan belajar mengajar berjalan dengan baik dan dapat mengaktifkan siswa dalam proses pembelajaran. Pada pertemuan 1 ini peneliti menggunakan metode Drill. Kegiatan pembelajaran yang akan dilakukan oleh guru menggunakan metode Drill adalah guru menyampaikan informasi materi dan informasi tujuan pembelajaran, guru menerangkan materi dan memberikan contoh gerakan servis atas, siswa melaksanakan tes individu untuk mengukur pemahaman siswa mengenai materi yang telah diberikan. Di akhir kegiatan guru membagikan lembar soal siswa terhadap kegiatan pembelajaran dengan menggunakan metode Drill.

Kegiatan observasi atau pengamatan dilakukan selama proses pembelajaran pertemuan 1 berlangsung. Pengamatan dilakukan oleh guru kelas VB yang bertindak sebagai observer dan peneliti. Pada tahap ini peneliti membuat catatan hasil pengamatan terhadap aktifitas dan kinerja siswa selama proses pembelajaran. Pengamatan yang dilakukan oleh guru kelas VB yang bertindak sebagai observer meliputi pengamatan aktivitas guru (peneliti) dalam mengelola pembelajaran, aktivitas siswa selama proses pembelajaran berlangsung. Pengamatan dilakukan dengan berpedomanpada instrumen yang telah dibuat sebelumnya.

Pada tahap refleksi merupakan tahap menganalisis dan refleksi dari pengamatan selama proses pembelajaran yang telah berlangsung. Refleksi dilakukan untuk mengetahui tingkat keberhasilan tindakan pada siklus sebelumnya. Peneliti mengidentifikasi dan mengelompokkan permasalahan yang muncul, apabila ditemukan permasalahan pada siklus I maka dapat diperbaiki pada siklus selanjutnya.

\section{Instrumen Penelitian}

Instrumen Penelitianini adalah dengan menggunakan (1) lembar observasi guru, (2) lembar observasi siswa dan (3) tes.

\section{Analisis data}

Analisis data dilakukan setelah pelaksanaan tindakan setiap siklus. Teknik analisis data yang digunakan dalam penelitian ini adalah teknik analisis data kuantitatif data yang terkumpul dipilah dan diklasifikasi dicari data yang paling tepat.

\section{Data hasil observasi guru}

Analisis data yang berasal dari observasi guru menguraikan data yang telah dibuat pengamat. Aspek-aspek yang diamati dijelaskan secara terperinci dalam lampiran. Penilaian pada observasi guru adalah skor yang diperoleh dibagi skor maksimum dan dikalikan 100. Apabila hasil yang diperoleh lebih dari $80 \%$ dari skor total maka guru sudah menerapkan metode drill dan bermain dengan baik. Skor akhir $=\frac{\text { jumlahskoryangdiperoleh }}{\text { skormaksimum }} \times 100$

Kriteria taraf keberhasilan ditentukan sebagai berikut:

$$
\begin{aligned}
85 \%<\mathrm{P} \leq 100 \% & =\text { Sangat Baik }(\mathrm{A}) \\
70 \%<\mathrm{P} \leq 84 \% & =\text { Baik }(\mathrm{B}) \\
55 \%<\mathrm{P} \leq 69 \% & =\text { Cukup }(\mathrm{C})
\end{aligned}
$$




$$
\begin{array}{cl}
40 \% & <\mathrm{P} \leq 54 \% \\
0 \% & <\mathrm{P} \leq 39 \%
\end{array}
$$

\section{Data hasil observasi siswa}

Data hasil observasi siswa diambil dari nilai aktivitas siswa saat proses pembelajaran berlangsung. Penilaian aktivitas siswa diperoleh dengan skor yang diperoleh dibagi dengan skor maksimum dikali 100. Apabila hasil presentase menunjukkan kenaikan pada setiap siklus maka kegiatan yang dilakukan siswa sudah baik.

$$
\text { Perolehan nilai }=\frac{\text { jumlahskoryangdiperoleh }}{\text { skormaksimum }} \times 100
$$

Data hasil penilaian sikap siswa selama proses pembelajaran.

Data hasil penilaian sikap siswa selama proses pembelajaran diperoleh dengan cara dianalisa secara diskriptif

\section{Data hasil penilaian psikomotor selama proses pembelajaran.}

Data yang terkumpul dianalisis dengan statistik deskriptif untuk mengetahui :

Nilai rata-rata post test, dapat dimaterikan sebagai berikut

$$
\dot{X}=\frac{\sum X}{\sum N}
$$

Keterangan:

$\dot{X}=$ Nilai rata-rata kelas

$\sum X=$ Jumlah semua nilai siswa

$\sum N=$ Jumlah Siswa (Sudjana, $1989: 109$ )

\section{Ketuntasan Belajar secara individu (prestasi belajar siswa)}

Untuk menghitung ketuntasan belajar secara individu digunakan materi:

Ketuntasan Individu $=\frac{\sum \text { siswayangmendapatnilai } \geq 75}{\sum \text { siswa }} \times 100 \%$

(USDn, 1993 : 138)

\section{Ketuntasan Belajar secara klasikal}

Untuk menghitung persentase ketuntasan belajar klasikal digunakan materi sesuai pendapat Mulyasa (2003:102) sebagai berikut :

$$
P=\frac{\sum \text { Siswayangtuntasbelajar }}{\sum \text { Siswa }} \times 100 \%
$$

Peningkatan hasil belajar siswa dapat diketahui dari hasil tes yang dicari nilai rata-ratanya. Untuk peningkatan hasil belajar maka digunakan nilai yang diperoleh siswa yang disesuaikan dengan KKM sebagai indikator peningkatan hasil.

\section{Ketuntasan belajar}

383 BRILIANT: Jurnal Riset dan Konseptual

Volume 2 Nomor 3, Agustus 2017 
Ketuntasan belajar siswa merupakan pemahaman siswa secara penuh terhadap suatu materi yang dibuktikan degan hasil belajar yang baik pada materi tersebut. Patokan penilaian menggunakan Kriteria Ketuntasan Minimal (KKM) yang ditentukan oleh SDN Turi 1 Kota Blitar dimana siswa dikatakan tuntas belajar apabila nilai siswa mencapai nilai $\geq 80$. Secara klasikal dalam satu kelas dianggap telah tuntas jika siswa yang mendapat nilai $\geq 80$ memperoleh persentase $80 \%$ dari siswa satu kelas. Hal ini artinya $80 \%$ dari seluruh kelas memperoleh nilai akhir $\geq 75$ Untuk mengetahui ketuntasan belajar secara klasikal dapat menggunakan rumus sebagai berikut.

$$
\text { ketuntasan belajarklasikal }=\frac{\text { jumlahsiswayangtuntasindividual }}{\text { jumlahseluruhsiswadalamkelas }} \times 100
$$

\section{HASIL}

Siklus I

Siklus I merupakan tahap pertama dalam penelitian ini. Siklus ini menggunakan SK. 6 Mempraktekkan berbagai gerak dasar salah satu permainan dan olahraga dengan peraturan yang dimodifikasi dan nilai-nilai yang terkandung didalamnya dan KD 6.2. Mempraktekan pengembangan koordinasi beberapa nomor permainan serta nilai sportifitas, percaya diri dan kejujuran. Siklus I ini dilakukan dalam dua pertemuan, yaitu pada tanggal 23 dan 30 Agustus 2016. Alokasi waktu yang digunakan dalam satu kali pertemuan adalah 4x35 menit dengan pembahasan materi yang berbeda pada setiap pertemuan. Pada tahap ini peneliti bertindak sebagai guru dan observer bagi aktivitas belajar siswa, sedangkan guru kelas bertindak sebagai observer bagi pembelajaran yang dilakukan oleh guru.

Pada tahap perencanaan peneliti melakukan : (1) mempersiapkan silabus sebagai bahan acuan dalam pengembangan RPP, (2) membuat RPP yang sesuai dengan metode pembelajaran Drill, (3) menyiapkan media dan sumber pembelajaran, (4) menyiapkan instrumen penilaian. Instrumen penilaian yang disiapkan meliputi tes akhir berupa tes afektif, tes psikomotor dan tes tulis, lembar observasi siswa, dan (5) kamera sebagai alat dokumentasi.

Tahap pelaksanaan ini terbagi menjadi dua pertemuan, pertemuan I dan pertemuan II. Hasil dari tahap pelaksanaan ini dapat dipaparkan sebagai berikut.

Siklus I pertemuan ke-1 dilaksanakan pada hari Selasa 23 Agustus 2016 pada jam pelajaran ke-1 sampai ke-4. Alokasi waktu yang digunakan adalah $4 \mathrm{x}$ 35 menit. Muatan materi yang diambil adalah mengenai passing bawah dan passing atas. Kegiatan awal dimulai dengan guru memberikan salam, do'a, pemanasan dan melakukan presensi. Pembelajaran dilanjutkan dengan melakukan apersepsi melalui tanya jawab berkaitan dengan bolavoli. Selanjutnya siswa diberikan informasi materi yaitu passing bawah dan passing atas melalui metode drill

Kegiatan inti dimulai dengan guru menyampaikan materi passing bawah dan passing atas. Kemudian Guru memberi contoh tentang passing bawah dan passing atas. Guru melakukan tanya jawab mengenai topik dan tujuan materi yang akan dipelajari. Anak dibagi 2 bersaf dan membimbing siswa melakukan passing bawah dan atas secara berhadapan.

384 BRILIANT: Jurnal Riset dan Konseptual

Volume 2 Nomor 3, Agustus 2017 
Kegiatan akhir berupa siswa diberikan tes akhir berupa soal tes tulis untuk mengetahui tingkat pengetahuan siswa terhadap materi yang disampaikan. Selanjutnya siswa dibimbing oleh guru untuk menarik kesimpulan dari pembelajaran yang sudah dilaksanakan. Siswa diberikan kesempatan untuk menanyakan kembali materi yang belum dipahami. Guru bersama siswa melakukan refleksi terhadap kegiatan pembelajaran, siswa diminta untuk menyampaikan kesan terhadap pembelajaran yang diikuti. Pembelajaran diakhiri dengan pendinginan, do'a dan salam.

Pertemuan ke-2 dilaksanakan pada hari Selasa, 30 Agustus 2016 pada jam pelajaran ke-1 sampai ke-4 dengan alokasi waktu 4x35 menit. Kegiatan awal dalam pembelajaran ini sama denggan yang dilakukan pada pertemuan pertama. Kegiatan diawali dengan salam, doa pemanasan dan memeriksa kehadiran siswa. Kegiatan dilanjutkan dengan apersepsi. Apersepsi pada pertemuan ini dilakukan dengan melakukan tanya jawab tentang materi yang akan disampaikan dengan dikaitkan pada muatan materi sebelumnya dengan menunjukkan gambar servis atas dan atas. Selanjutnya guru memberi contoh dan anak mempraktekan servis atas bergantian.

Dilanjutkan Guru memberi contoh servis atas. Guru melakukan tanya jawab mengenai topik dan tujuan materi yang akan dipelajari. Guru menyuruh anak melakukan cara passing atas secara bergantian. Kegiatan akhir berupa siswa diberikan tes akhir berupa soal tulis untuk mengetahui tingkat pengetahuan siswa terhadap materi yang disampaikan. Selanjutnya siswa dibimbing oleh guru untuk menarik kesimpulan dari pembelajaran yang sudah dilaksanakan. Siswa diberikan kesempatan untuk menanyakan kembali materi yang belum dipahami.

Guru bersama siswa melakukan refleksi terhadap kegiatan pembelajaran, siswa diminta untuk menyampaikan kesan terhadap pembelajaran yang diikuti. Pembelajaran diakhiri dengan pendinginan, do'a dan salam.

Kegiatan observasi dilaksanakan saat proses pembelajaran Penjaskes berlangsung. Kegiatan observasi difokuskan pada pelaksanaan pembelajaran. Dalam kegiatan ini, Guru mengamati aktvitas siswa.

Kedua, Guru mengamati langkah-langkah kegiatan siswa ketika melaksanakan kegiatan pembelajaran, sudah sesuaikah langkah yang ditempuh siswa dengan langkah-langkah yang tertera dalam lembar kegiatan. Observasi dilaksanakan selama proses pembelajaran berlangsung. Observasi dilakukan terhadap aktivitas siswa, guru, dan hasil belajar siswa. Hasil belajar siswa yang berupa nilai akhir diperoleh dari nilai proses, tes afektif, dan nilai tes tulis akhir pembelajaran. Nilai afektif diperoleh melalui pengamatan maka dari 25 siswa ada 3 siswa yang belum melakukan do'a dengan baik $22(88 \%)$ siswa sudah melakukan do'a dengan baik.

Hasil observasi aktivitas guru pada siklus I adalah sebagai berikut.: Aktivitas guru pada siklus I pertemuan I adalah sebesar $80 \%$ dan meningkat pada pertemuan II menjadi sebesar 90\%. Dari data hasil siklus I pertemuan 1 dan 2 dapat diketahui bahwa rata-rata aktivitas guru dalam pembelajaran yaitu sebesar $85 \%$ dengan hasil kualifikasi baik.

Hasil observasi aktivitas siswa selama proses pembelajaran siklus I meliputi yaitu bermain dan kelincahan sesuai dengan langkah-langkah yang dilakukan oleh guru. Informasi yang didapat pada pertemuan I menunjukkan 1 indikator tampak dari 2 indikator yang ingin dicapai oleh guru. Jika 
dipersentasekan, maka aktivitas siswa pada pertemuan 1 adalah sebesar 77,5\% sedangkan pada pertemuan 2 , dapat diketahui persentase untuk aktivitas siswa adalah sebesar $80.5 \%$. Pada pertemuan ke-2 sebanyak 2 indikator yang ingin dicapai. Dari hasil tersebut dapat diketahui rata-rata aktivitas belajar siswa sebesar $79 \%$.

Rendahnya aktivitas belajar siswa dikarenakan siswa belum mengenal dan memahami langkah-langkah dalam bermain bolavoli, siswa kurang mampu dalam memahami materi dan mempraktekannya sesuai penjelasan guru.

Nilai hasil belajar diperoleh dari nilai tes akhir siswa pada akhir pembelajaran siklus I. diperoleh informasi bahwa dari 25 siswa terdapat 6 siswa telah mencapai ketuntasan belajar individu sedangkan 19 siswa belum mampu mencapai nilai ketuntasan individu.

Ketuntasan belajar klasikal (KBK) pada siklus I sebesar $24 \%$ dengan kualifikasi kurang. Rata-rata hasil belajar siswa meningkat jika dibandingkan dengan ketercapaian ketuntasan belajar klasikal pada pertemuan 1 yaitu sebesar $74,4 \%$ dan meningkat menjadi $78,4 \%$ pada pertemuan 2

Refleksi pertemuan ke-1 antara lain : a) Guru hendaknya penyampaian langkah-langkah dengan jelas. b) Guru belum mampu memotivasi siswa c) Guru dapat mengoreksi dan membetulkan kesalahan-kesalahan dengan benar. Refleksi pada pertemuan ke-2 yaitu a) Guru hendaknya sebelum memberi contoh memberi penjelasan terlebih dahulu b) Guru hendaknya dapat membuat anak senang melakukan dan tidak takut c) Guru hendaknya memberi semangat d) Guru hendaknya perlu membimbing siswa agar lebih berani dan percaya diri.

\section{Siklus II}

Setelah melakukan refleksi terhadap pelaksanaan siklus I, peneliti perlu melakukan perbaikan pembelajaran mengenai bolavoli melalui metode drill pada pelaksanaan siklus II agar diperoleh peningkatan hasil belajar yang lebih baik jika dibandingkan dengan siklus I.

Pada tahap perencanaan peneliti melakukan : (1) mempersiapkan silabus sebagai bahan acuan dalam pengembangan RPP, (2) membuat RPP yang sesuai dengan metode pembelajaran Drill, (3) menyiapkan media dan sumber pembelajaran, (4) menyiapkan instrumen penilaian. Instrumen penilaian yang disiapkan meliputi tes akhir berupa tes afektif, tes psikomotor dan tes tulis, lembar observasi siswa, dan (5) kamera sebagai alat dokumentasi.

Tahap pelaksanaan ini terbagi menjadi dua pertemuan, pertemuan 1 dan pertemuan 2. Hasil dari tahap pelaksanaan ini dapat dipaparkan sebagai berikut.

Siklus II pertemuan ke-1 dilaksanakan pada hari Selasa 6 September 2016 pada jam pelajaran ke-1 sampai ke-4. Alokasi waktu yang digunakan adalah 4 x 35 menit. Muatan materi yang diambil adalah cara smash dan cara bloking. Kegiatan awal dimulai dengan guru memberikan salam, do'a, pemanasan dan melakukan presensi. Pembelajaran dilanjutkan dengan melakukan apersepsi melalui tanya jawab bolavoli kepada siswa. Selanjutnya siswa diberikan informasi materi yaitu smash melalui metode drill.

Kegiatan inti dimulai dengan guru menyampaikan materi smash. Kemudian Guru memberi contoh cara smash. Guru melakukan tanya jawab mengenai topik dan tujuan materi yang akan dipelajari. Guru menyuruh anak melakukan smash satu persatu.

386 BRILIANT: Jurnal Riset dan Konseptual

Volume 2 Nomor 3, Agustus 2017 
Dilanjutkan Guru memberi contoh cara membloking. Guru melakukan tanya jawab mengenai topik dan tujuan materi yang akan dipelajari. Guru menyuruh anak melakukan cara membloking satu persatu.

Pada kegiatan akhir, siswa diberikan tes akhir berupa soal tulis untuk mengetahui tingkat pengetahuan siswa terhadap materi yang disampaikan. selanjutnya siswa dibimbing oleh guru untuk menarik simpulan dari pembelajaran yang sudah dilaksanakan. Siswa diberikan kesempatan untuk menanyakan kembali materi yang belum dipahami. Guru bersama siswa melakukan refleksi terhadap kegiatan pembelajaran, siswa diminta untuk menyampaikan kesan terhadap pembelajaran yang diikuti. Pembelajaran diakhiri dengan pendinginan doa dan salam.

Siklus II pertemuan ke-2 dilaksanakan pada hari Selasa 13 September 2016 pada jam pelajaran ke-1 sampai ke-4. Alokasi waktu yang digunakan adalah 4 x 35 menit. Muatan materi yang diambil adalah menjelaskan peraturan dan cara bermain bolavoli. Kegiatan awal dimulai dengan guru memberikan salam, do'a, pemanasan dan melakukan presensi.

Kegiatan inti dimulai dengan guru menjelaskan peraturan bolavoli dan cara bermain bolavoli .Kemudian siswa melakukan permainan bolavoli Guru melakukan tanya jawab mengenai topik dan tujuan materi yang akan dipelajari. Kegiatan tersebut dapat dilihat pada halaman 155-156.

Kegiatan akhir berupa siswa diberikan tes akhir berupa soal tulis untuk mengetahui tingkat pengetahuan siswa terhadap materi yang disampaikan. Selanjutnya siswa dibimbing oleh guru untuk menarik kesimpulan dari pembelajaran yang sudah dilaksanakan. Siswa diberikan kesempatan untuk menanyakan kembali materi yang belum dipahami. Guru bersama siswa melakukan refleksi terhadap kegiatan pembelajaran, siswa diminta untuk menyampaikan kesan terhadap pembelajaran yang diikuti. Pembelajaran diakhiri dengan pendinginan, do'a dan salam.

Observasi dilaksanakan selama proses pembelajaran berlangsung. Observasi dilakukan terhadap aktivitas siswa, guru, dan hasil belajar siswa. Hasil belajar siswa yang berupa nilai akhir diperoleh dari nilai proses, tes afektif, dan nilai tes tulis akhir pembelajaran. Nilai proses diperoleh dari hasil observasi peneliti terhadap sikap yang ditunjukkan siswa selama mengikuti aktivitas pembelajaran yang dilakukan oleh guru dan keterampilan yang ditunjukkan oleh siswa dalam menyelesaikan tugas. Observasi dalam aspek sikap menyangkut kriteria bermain dan kelincahan, sedangkan psikomotor diperoleh dari keterampilan cara bermain dan cara menerapkan peraturannya yang dilakukan oleh siswa. Hasil observasi aktivitas guru pada siklus II adalah sebesar $85 \%$ dan meningkat pada pertemuan 2 menjadi sebesar 95\%. Dari data hasil siklus II pertemuan 1 dan 2 dapat diketahui bahwa rata-rata aktivitas guru dalam pembelajaran yaitu sebesar $90 \%$ dengan hasil kualifikasi sangat baik.

Hasil observasi aktivitas siswa selama proses pembelajaran siklus II meliputi yaitu bermain dan kelincahan sesuai dengan langkah langkah yang dilakukan oleh guru. Informasi pada pertemuan II menunjukkan 2 indikator yang sudah dicapai oleh guru. Aktivitas siswa pada pertemuan 1 adalah sebesar $85 \%$ sedangkan pada pertemuan 2 sebesar 86,5\%. Dari hasil tersebut dapat diketahui rata-rata aktivitas belajar siswa sebesar $85,75 \%$ 
Hasil belajar siswa pada siklus II Pertemuan ke-2 diperoleh informasi bahwa dari 25 siswa telah mencapai ketuntasan belajar individu. Ketuntasan belajar klasikal (KBK) pada siklus II sebesar $100 \%$ dengan kualifikasi baik. Berdasarkan informasi ketuntasan pada siklus II maka tidak perlu diadakan siklus lanjutan.

Refleksi pada siklus II yaitu terdapat peningkatan hasil bermain yang signifikan pada hasil belajar siswa dan aktifitas guru. hal tersebut dapt diketahui melalui perbandingan peningkatan ketuntasan belajar klasikal siswa dari kegiatan pembelajaran siklus I dan siklus II serta keberhasilan guru dalam mengelola waktu, kelas dan pembelajaran

\section{Temuan}

Berdasarkan kegiatan yang dilakukan dari siklus I sampai siklus II ditemukan beberapa hal, diantaranya : (a) siswa dapat mengikuti dengan baik, (b) aktifitas yang dilakukan siswa dalam pembelajaran meningkat. Dapat diketahui hasil belajar siswa pada siklus I rata-rata persentase aktifitas guru sebesar $85 \%$, rata-rata pada nilai akhir siswa sebesar 76,6\%, pada akhir ketuntasan belajar siswa sebesar 24\%, sedangkan pada siklus II rata-rata persentase aktifitas guru sebesar $90 \%$, rata-rata nilai akhir siswa $83,7 \%$. Pada nilai akhir siswa diperoleh ketuntasan belajar sebesar $1005 \%$ dan yang belum tuntas $0 \%$.

\section{PEMBAHASAN}

\section{Penerapan Metode Drill pada Siswa Kelas VB SDN Turi 1 Kota Blitar}

Peningkatkan Hasil Belajar Siswa pada Mata Pelajaran Pendidikan Jasmani dan Kesehatan Tentang Servis Atas Permainan Bolavoli Dengan Menggunakan Metode Drill Dan Bermain Di Kelas VB dilakukan dalam dua siklus, yaitu siklus I dan siklus II. Dari hasil pelaksanaan pembelajaran dari tahap siklus I, dan siklus II hasil bermain siswa mengalami peningkatan.

Kegiatan pembelajaran melalui metode drill siklus I sudah terlaksana baik. Pembelajaran yang dilakukan guru telah sesuai dengan RPP yang disusun menggunakan metode drill. Langkah langkah kegiatan pembelajaran yang dilaksanakan guru adalah : (1) persiapkan alat-alat yang diperlukan, (2) guru menjelaskan kepada anak -anak apa yang direncanakan dan apa yang akan dikerjakan, (3) guru memberi contoh kepada anak-anak secara perlahan-lahan, serta memberikan penjelasan yang cukup, (4) guru mengoreksi dan membetulkan kesalahan kesalahan, (5) guru menugaskan kepada siswa agar melakukan yang dicontohkan guru, dan (6) guru melakukan evaluasi dengan memberikan tes akhir kepada siswa.

Secara keseluruhan pembelajaran yang dilakukan telah memenuhi langkah-langkah pembelajaran metode drill. Namun, ada pelaksanaan pembelajaran yang tidak sesuai dengan target yang ingin dicapai dalam pelaksanaan siklus I. Beberapa hal yang muncul dan berpengaruh dala aktifitas bermain dan hasil bermain siswa antara lain : (1) adanya siswa yang berbicara sendiri selama pembelajaran, (2) tidak adanya penghargaan ynag diberikan oleh guru kepada siswa membuat siswa kurang antusias dalam melakukan pembelajaran. Motivasi bisa muncul jika terdapar penghargaan atau pujian yang layak yang menyertai atau melandasi pembelajaran. 
Hal ini tentu sangat mempengaruhi kualitas bermain siswa, sehingga diperlukan cara untuk meningkatkan hasil bermain siswa pada siklus berikutnya. Djamarah (2006:17) menjelaskan bahwa suasana belajar yang tidak lagi menyenangkan bagi anak didik biasanya lebih banyak mendatangkan kegiatan belajar yang harmonis. Hal ini tidak sesuai dengan tujuan pembelajaran penjaskes yang dikemukakan oleh Suherman (2000:22) Penjasorkes merupakan proses pendidikan yang memanfaatkan aktivitas jasmani dan direncanakan secara sistematik bertujuan untuk meningkatkan individu secara organik, neuromuscular, perseptual, kognitif, social, dan emosional.

Paparan di atas berdampak pada hasil bermain siswa. Pada siklus I nilai akhir masih banyak yang berada dibawah KKM. Namun jika dibandingkan dengan nilai akhir pada pertemuan sehari-hari telah menunjukan peningkatan. Dalam aspek kognitif yang membuat siswa tidak tuntas adalah adanya kurang mengerti langkah-langkah pembelajaran. Adanya kesulitan kesulitan yang dialami siswa. Guru perlu memberikan bimbingan secara perlahan-lahan.

Pembelajaran pada siklus II dapat berjalan dengan baik. Guru melakukan pembelajaran sesuai RPP baik dalam langkah kegiatan maupun alokasi waktu yang digunakan. Aktifitas guru pada siklus II mencapai 90\%. Guru mampu memotivasi siswa lebih aktif dalam pembelajaran dengan cara mempertegas langkah-langkah pembelajaran.

Nilai akhir siswa dalam pembelajaran siklus II meningkat jika dibandingkan dengan tahap siklus I. Peningkatan hasil belajar siswa ini diperoleh setelah guru mampu memaksimalkan penggunaan metode drill. Penggunaan metode drill dapat meningkatkan hasil bermain sehingga hasil belajar yang diperoleh siswa meningkat.

\section{Peningkatan Hasil Belajar Siswa}

Aktifitas belajar mengalami peningkatan pada siklus I, hingga siklus II. Pada siklus I sebesar 76,6\% dengan kualifikasi baik dan meningkat pada siklus II menjadi $83,7 \%$ dengan kualitas sangat baik. SDN Turi 1 Kota Blitar menetapkan KKM untuk mata pelajaran Penjaskes sebesar 75. Aktifitas belajar siswa meningkat dari siklus I sebesar $79 \%$ menjadi $85,75 \%$ pada siklus II.

Pada siklus I aktifitas belajar siswa dan hasil bermain siswa baik dari aspek kognitif, afektif, dan psikomotor mengalami peningkatan. Hasil belajar yang diperoleh siswa pada pertemuan siklus I mencapai rata-rata 76,6\% dengan presentase ketuntasan belajar klasikal sebesar $24 \%$.

Pembelajaran yang dilakukan oleh guru pada siklus II pertemuan ke-1 memiliki rata-rata sebesar $85 \%$, sedangkan pada sikluis II pertemuan 2 memiliki rata-rata sebesar 90\%. Dari sebanyak 25 siswa yang dinyatakan tidak tuntas hanya 3 pada pertemuan ke-1, dan keseluruhan siswa dinyatakan tuntas pada pertemuan ke-2. Ketuntasan siswa pada pertemuan ke-1 sebesar 83,2 \% dan pada pertemuan ke-2 sebesar $100 \%$. Peningkatan hasil bermain yang dicapai siswa dikarenakan perubahan yang dilakukan oleh guru terutama pada pengelolaan waktu dan penggunana metode yang tepat. Aktifitas belajar siswa meningkat dari $85 \%$ pada pertemuan ke-1 menjadi $86,5 \%$ pada pertemuan ke-2. Siswa yang semula kebingungan dalam mengikuti pembelajaran, telah mampu mengikuti pembelajarn metode drill. Hal ini sesuai dengan pendapat tentang kelebihan metode drill menurut Roestiyah N.K (1985: 125).

389 BRILIANT: Jurnal Riset dan Konseptual Volume 2 Nomor 3, Agustus 2017 
(a)Bahan yang diberikan secara teratur, tidak loncat-loncat dan step by step akan lebih melekat pada diri anak dan benarbenar menjadi miliknya. (b)Adanya pengawasan, bimbingan dan koreksi yang segera diberikan oleh guru memungkinkan murid untuk segera melakukan perbaikan terhadap kesalahan-kesalahannya. Dengan demikian juga akan menghemat waktu belajarnya. (c) Pengetahuan atau keterampilan siap yang telah tebentuk sewaktu-waktu dapat dipergunakan dalam keperluan sehari-hari, baik untuk keperluan studi maupun untuk bekal hidup di masyarakat kelak. (d) Untuk memperoleh kecakapan motoris, seperti menulis, menghafalkan huruf, kata-kata atau kalimat, membuat alat-alat, menggunakan alat-alat (mesin permainan dan atletik), dan terampil menggunakan peralatan olahraga. (e) Pembentukan kebiasaan yang dilakukan dan menambah ketepatan serta kecepatan pelaksanaan.(f) Pembentukan kebiasaan-kebiasaan membuat gerakan-gerakan yang kompleks, rumit, menjadi lebih otomatis. (g) Dapat menambah minat siswa terhadap pelajaran mereka. (h) dapat membangkitkan perasaan sukses bagi siswa yang dapat menguasai lebih dari satu kemampuan yang spesifik.

Nilai hasil pembelajaran siklus II pertemuan ke-1 memiliki rata-rata sebesar $80 \%$, sedangkan pada pertemuan ke-2 sebesar $83,75 \%$. Pada pertemuan ke-1 dari 25 siswa sebanyak 22 siswa atau $80 \%$ telah dinyatakan tuntas belajar, sedangkan 3 siswa atau $20 \%$ dinyatakan belum tuntas. Pada pertemuan 2 sebanyak 24 siswa atau jika dipersentasikan 100\% dinyatakan tuntas belajar. Dengan perolehan nilai hasil sebesar $83.75 \%$ pada siklus II pertemuan ke-2 maka kelas dapat dinyatakan telah melampui batas ketuntasan klasikal sebesar $75 \%$ dan siklus dinyatakan telah berhasil.

Berdasarkan hasil pada siklus I dan siklus II yang mengalami peningkatan jika dibandingakan dengan tahap sebelumnya dan tidak perlu dilakukan siklus lanjutan. Hal ini dibuktikan dengan peningkatan keberhasilan guru yang diketahui dari hasil observasi guru dari tahap siklus I pertemuan 1 sebesar $84 \%$ meningkat di pertemuan ke-2 sebesar $88 \%$ dan pada siklus II pertemuan ke-1 sebesar $90 \%$ meningkat pertemuan ke-2 sebesar $95 \%$. Nilai ketuntasan belajar klasikal dari tahap siklus I sebesar 58,34 \% meningkat sebesar $100 \%$ pada siklus II. Hasil belajar siswa mengalami peningkatan dilihat dari rata rata hasil belajar pada siklus I sebesar 72,29 \% dan meningkat pada siklus II sebesar $81,66 \%$. Dapat diartikan bahwa siswa mampu melampui KKM yang ditetapkan sekolah sebesar 75 .

\section{KESIMPULAN}

Berdasarkan hasil penelitian, pembahasan dan kajian pustaka maka dapat diperoleh simpulan sebagai berikut : 1) Penerapan metode dril pada pembelajaran penjaskes materi bolavoli dapat dilaksanakan dengan baik. Siswa terlibat aktif selama pembelajaran sehingga aktivitas belajar dan hasil belajar yang diperoleh siswa pada materi ini meningkat. 2) Melalui Peningkatan hasil bermain penjaskes materi Servis Atas Bolavoli dengan Menggunakan Metode Drill dan Bermain di Kelas VB SDN Turi 1 Kota Blitar dapat meningkatkan aktivitas dan hasil belajar siswa secara optimal, dibuktikan dengan hasil belajar siswa yang dapat dipaparkan dalam ketuntasan belajar klasikal yang mengalami peningkatan secara konsisten dan hingga mencapai $100 \%$ pada akhir pertemuan. Melalui metode drill

390 BRILIANT: Jurnal Riset dan Konseptual Volume 2 Nomor 3, Agustus 2017 
meningkatkan hasil belajar siswa baik dalam aspek kognitif, afektif dan psikomotor.

\section{SARAN}

Berdasarkan temuan penelitian hasil belajar dan kesimpulan dalam penelitian ini, peneliti memberikan saran sebagai berikut. 1) Guru hendaknya sebelum menyampaikan tujuan pembelajaran sebelum memasuki kegiatan inti. 2) Guru hendaknya memperhatikan kesesuaian antara materi ajar dengan lingkungan di mana siswa belajar serta memperlakukan semua siswa secara adil. 3) Guru hendaknya dapat membuat anak senang melakukan dan tidak takut. 4) Guru hendaknya perlu membimbing siswa agar lebih berani dan percaya diri. 5) Guru hendaknya selalu memotivasi siswa.

\section{DAFTAR RUJUKAN}

Djamarah, S. B., \& Zain, A. 2006. Strategi Belajar Mengajar. Jakarta: Rineka Cipta

Herry Koesyanto, 2003. Belajar Bermain Bola Bolavoli. Jakarta: Universitas Terbuka

K, Beutelstahl Dieter. 2005. Belajar Bermain Bolavoli. Bandung: Pioner Jaya.

Kemmis, S., \& Taggart, R. 1990. The actioan Research Planner. Victoria: Deakin University.

Rusli, Lutan. 1988. Belajar Keterampilan Motorik, Pengantar Teori dan Metode. Jakarta: Depdikbud Dirjen Dikti PPLPTK

Roestiyah, N. K. 1985. Metodologi Pembelajaran. Jakarta: Rineka Cipta

Sabri, M. Alisuf. 1995. Psikologi Pendidikan, Jakarta: Pedoman Ilmu Jaya.

Sudjana, N. 1989. Pembinaan dan pengembangan kurikulum di sekolah. Jakarta: Sinar Baru.

Sudjana, Nana. 2005. Pengantar Penelitian Pendidikan. Jakarta : Bina Aksara

Sugiyanto. 1993. Belajar Gerak. Jakarta: KONI.

Suharno, HP. 1989. Dasar-Dasar Permainan Bolavoli. Yogyakarta: IKIP Yogyakarta.

Suherman, A. 2000. Dasar-dasar Penjaskes. Jakarta: Depdiknas.

Yunus, M. 1992. Olahraga Pilihan Bola Voli. Jakarta: Depdikbud 